\title{
Estimation of Soluble, Insoluble and Total Oxalate Contents in Common Edible Mushrooms of West Bengal, India
}

\author{
Rishu Sharma* and Binoy Gorai \\ Department of Plant Pathology, Bidhan Chandra Krishi Visvavidyalya, \\ Mohanpur, West Bengal, India \\ *Corresponding author
}

\section{A B S T R A C T}

Keywords

Mushrooms, oxalates, Kidney stones, Calcium oxalates

Article Info

Accepted:

04 June 2018

Available Online:

10 July 2018
Oxalates in edible mushrooms are the new concept for mitigating the kidney stones in humans. In the present study, a total of nine edible mushroom species were collected, out of which six were procured from the local vendors, growers and three from wild areas of West Bengal. The sporocarps of the collected mushroom were sterilized with alcohol and cleaned to detect oxalate contents in edible mushroom species. The total oxalate content of the raw, commercially grown mushrooms ranged from 44.1 to $92.3 \mathrm{mg} / 100 \mathrm{~g} \mathrm{DM}$ while the values for the soluble oxalate contents of the mushrooms ranged from 36.2 to 65.2 $\mathrm{mg} / 100 \mathrm{~g}$ DM. Apart from the three cultivars collected from the wild viz. Tremella spp., Boletus spp and Schizophylum spp., which showed a non-detectable amount of insoluble oxalates while the cultivated mushrooms showed the presence of insoluble oxalates mostly. Mushrooms harvested from the forest contained only soluble oxalate with the levels ranging from 36.2 to $44.1 \mathrm{mg} / 100 \mathrm{~g}$ DM in the raw tissue. Thus, we can conclude that many edible mushrooms if consumed can reduce the recurrence of kidney stones radically.

\section{Introduction}

Oxalate is a molecule that has a pivotal role in preventing the absorption of calcium for mitigating the kidney stones in humans. Oxalate in food is either soluble or insoluble. Insoluble oxalate is bound to another molecule that makes it much harder to absorb; normally calcium but also sometimes magnesium. Oxalate is the dianion with the formula $\mathrm{C}_{2} \mathrm{O}^{2-}{ }_{4}$, also written $(\mathrm{COO})^{2-}{ }_{2}$. Either name is often used for derivatives, such as salts of oxalic acid, for example sodium oxalate $\mathrm{Na}_{2} \mathrm{C}_{2} \mathrm{O}_{4}$, (Anonymous, 2018). Many metal ions form insoluble precipitates with oxalate, a prominent example being calcium oxalate, the primary constituent of the most common kind of kidney stones. Soluble oxalate is not attached to another molecule and is more easily absorbed. The intake of soluble oxalate might be much more important than total oxalate. Oxalates are common constituents of plants (Franceschi and Loewus, 1995) but are usually minor components in human diets, 
important only in seasonal diets in certain areas of the world. Mushrooms have been consumed by tribes and farmers since ancient times (Sarma et al., 2010). In the present times, the mushrooms are widely cultivated and preferred among progressive farmers because of its ease of cultivation and ability to use lignocellulosic waste (Biswas and Biswas, 2015) The spent compost after mushroom cultivation is also used by tribes for various farming practices (Shitole et al., 2014). Calcium oxalate is a substance so generally found in the fungi that it is quite unnecessary to enumerate the instances of its occurrence (De Bary, 1887). Later, Hein (1930) described the appearance of the mycelia of $A$. campestris as having a more or less complete covering of needle-like crystals. Similar needle-like crystals were observed on the outer walls of the hyphae of Agaricus bisporus (Arnott and Whitney, 1984). Fungi such as Aspergillus niger, Penicillium, Mucor, Boletus sulfurens and Sclerotinia can synthesise oxalic acid up to $4-5 \mathrm{~g} / 100 \mathrm{~g}$ dry weight (DW) in isolated cultivation, in food- stuffs and on the surface of forages (Gontzea and Sutzescu, 1968; Fassett, 1973). The giant mushroom (Tricholoma giganteum), a large, edible fungi, is reported to contain $89 \mathrm{mg} / 100 \mathrm{~g} \mathrm{DW}$ oxalic acid (Fujita et al., 1991). Several edible, tropical species of mushrooms, including termite and ear mushrooms, have been reported to contain $80-220 \mathrm{~g}$ oxalate/100 g DW (Aletor, 1995). Noonan and Savage (1999) highlighted the lack of data available on the oxalate content of common foods, including fungi. Savage et al., (2000) showed that many high oxalate-containing foods contained both soluble and insoluble oxalates. Though, work has been done related to many oxalate producing fungi but very few reports have been found on common edible mushrooms. Thus, the present study was designed and carried out with the objective of determining the total, soluble and insoluble oxalate contents in some commercially available edible fungi of the region, some locally grown mushrooms and few from the wild. The focus on the products which could lower the incidence and severity of the kidney stones is being emphasized in the present study.

\section{Materials and Methods}

\section{Sample preparation}

The collected samples of 9 fresh mushrooms viz. Agaricus bisporus, Pleurotus ostreatus, Termitomyces heimi, Volvariella volvaceae, Auricularia polytricha, Pleurotus sajor caju, Tremella spp., Boletus spp, Schizophyllum spp. were collected from the local and wild during the rainy season i.e., July- August, 2016 (Fig. 1) The mushrooms were trimmed and peeled to remove any non-edible portions by following the standard Plant tissue culture technique (Murashige and Skoog, 1962). The sporocarp of each mushroom was chopped with a knife and approximately $200 \mathrm{~g}$ was placed in a saucepan with $50 \mathrm{ml}$ of water and boiled for $5 \mathrm{~min}$ by following the standard methodology of weighing (AOAC, 2000).

\section{Dry matter determination}

An approximate quantity of 3-4 g of fresh mushrooms was oven dried to constant weight at $105^{\circ} \mathrm{C}$ (AOAC, 2000).

\section{Total and soluble oxalic acid determinations}

Ten g samples of fresh mushroom of each sample were weighed into $250 \mathrm{ml}$ conical flasks and homogenised in $50 \mathrm{ml} 2 \mathrm{M} \mathrm{HCL}$ (Analar, BDH, UK) to extract the total oxalate content and $50 \mathrm{ml}$ distilled water (Barnstead Nanopure II) to extract the soluble oxalate content by the standard methodology (Hollaway et al., 1989). Each sample was analysed in three replications using the 
method outlined in detail by Albihn and Savage (2001).

\section{Statistical analysis}

The data are presented as the mean of three determinations \pm standard error.

\section{Results and Discussion}

A total of nine edible mushroom species were collected, out of which six were procured from the local vendors, growers and three from the wild areas of the West Bengal. The sporocarps of the collected mushroom were used to determine the presence/ absence and amount of Soluble, Insoluble and total oxalates in the collected edible mushrooms, which have been pioneer in controlling kidney stone formation (Anonymous, 2017). It has been estimated that the fungi contain the oxalic acid, however very less studies have been done to determine the content of oxalates in edible mushroom, which have been consumed by local tribes and farmers since ancient times (Sarma et al., 2010). In our studies, we observed that the total oxalate content of the raw, commercially grown mushrooms ranged from 44.1 to 92.3 $\mathrm{mg} / 100 \mathrm{~g}$ DM while the values for the soluble oxalate contents of the mushrooms ranged from 36.2 to $65.2 \mathrm{mg} / 100 \mathrm{~g}$ DM. Apart from the three cultivars collected from the wild viz. Tremella spp., Boletus spp and Schizophylum spp., which showed a non-detectable amount of insoluble oxalates while the cultivated mushrooms showed the presence of insoluble oxalates mostly. Mushrooms harvested from the forest contained only soluble oxalate with the levels ranging from 36.2 to $44.1 \mathrm{mg} / 100 \mathrm{~g}$ $\mathrm{DM}$ in the raw tissue. Our results are in conformity to the studies done by Noonan and Savage (1999), Savage et al., (2000) who also found that the levels of oxalates in cultivated fungi are relatively low and no insoluble oxalate could be found in the wild collected mushrooms.

The analytical response of the HPLC was different for the water and the acid extracts. The standard curve prepared using $2.0 \mathrm{M} \mathrm{HCl}$ always produced a lower response than the curve prepared using distilled water so the respective curves were used to calculate the water and acid extracted samples. The $r 2$ of the water prepared curve was 0.856 while the $r 2$ of the acid prepared curve was 0.892 . Similar result patterns were obtained by Savage et al., 2001), while working with edible mushrooms.

Table.1 Mean $( \pm$ SE) oxalate content of some commercially grown and some wild collected mushrooms mg/100g DM

\begin{tabular}{|l|l|l|l|l|}
\hline $\begin{array}{l}\text { S. } \\
\text { No }\end{array}$ & Mushrooms & $\begin{array}{l}\text { Total } \\
\text { Oxalates }\end{array}$ & $\begin{array}{l}\text { Soluble } \\
\text { Oxalates }\end{array}$ & $\begin{array}{l}\text { Insoluble } \\
\text { Oxalates }\end{array}$ \\
\hline $\mathbf{1}$ & Agaricus bisporus & $69 \pm 1.9$ & $49 \pm 2.4$ & 20 \\
\hline $\mathbf{2}$ & Pleurotus ostreatus & $89 \pm 3.4$ & $65 \pm 3.1$ & 24 \\
\hline $\mathbf{3}$ & Termitomyces heimi & $73 \pm 1.8$ & $52 \pm 1.1$ & 21 \\
\hline $\mathbf{4}$ & Volvariella volvaceae & $62 \pm 1.3$ & $45 \pm 1.4$ & 17 \\
\hline $\mathbf{5}$ & Auricularia polytricha & $92 \pm 2.8$ & $44 \pm 3.1$ & 88 \\
\hline $\mathbf{6}$ & Pleurotus sajor caju & $73 \pm 2.3$ & $52 \pm 2.2$ & 21 \\
\hline $\mathbf{7}$ & Tremella spp & $52 \pm 1.6$ & $40.4 \pm 1.4$ & - \\
\hline $\mathbf{8}$ & Boletus spp & $48 \pm 2.1$ & $36.2 \pm 1.5$ & - \\
\hline $\mathbf{9}$ & Schizophyylum spp & $44 \pm 1.3$ & $28.1 \pm 2.1$ & - \\
\hline *-= Not detectable amount & & & \\
\hline
\end{tabular}


Fig.1 Few edible mushroom species collected from the local markets and growers for oxalate determination
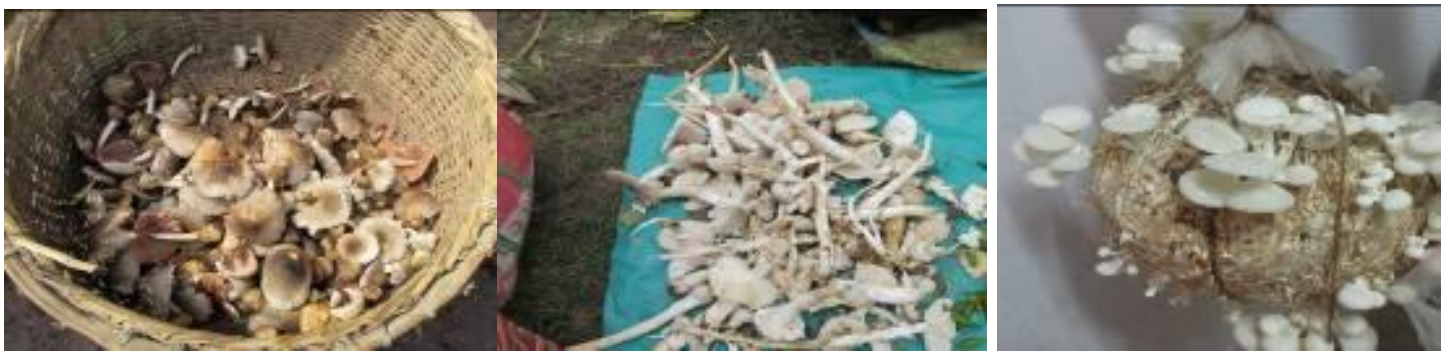

Mean values for the total, soluble and insoluble oxalic acid content of the raw collected mushrooms has been tabulated in Table 1. The mean dry matter content of the raw mushrooms was $6.51 \pm 0.06 \%$. Compared to other common oxalate-containing foods) the levels of oxalates in cultivated fungi are relatively low (Noonan and Savage, 1999; Savage et al., 2000). However, no insoluble oxalate could be found in the wild collected mushrooms.

Despite earlier observations of calcium oxalate crystals occurring on fungal hyphae (De Bary, 1887; Hein, 1930; Arnott and Whitney, 1984), the levels of oxalates found in the edible parts of cultivated mushrooms are low compared to other common oxalatecontaining vegetables. The levels of oxalates found in the three cultivars of edible fungi harvested from the forest are very low indeed. Our studies showed conformity to the results obtained by Noonan and Savage, 2000). The species Auricularia showed the highest range of insoluble oxalates but the total oxalates were highest in the same species followed by Pleurotus spp. Also, no detectable amount of insoluble oxalates were found in mushroom collected from the wild sources viz. Tremella spp., Boletus spp and Schizophyllum spp. Thus, it is a safe mode of nutritional intake and can be exploited well in the food industry to save people from kidney stones. The results obtained in the present study has inferred that besides having several nutritional and medicinal properties, mushrooms could be well explored as an additional diet option to lower the oxalates in the human body and thereby saving the people from kidney stones (Anonymous, 2017) and are in conformity to the work done by Noonan and Savage, 1999, Savage et al, 2000, 2001. But, before we conclude on increased intake of mushrooms, much more advanced and précised research is yet to be undertaken so as to make it a part of diet chart of patients suffering with kidney stones.

\section{References}

Anonymous. 2018. Oxalates. https://en. wikipedia.org/wiki/Oxalate

Anonymous. 2017. What Vegetables Should Help Kidney Stones? www.livstrong. com

AOAC. 2000. Official Methods of Analysis of AOAC International, 17th ed.; AOAC International: Gathersberg, MD, USA.

Albihn, P.B.E. and Savage, G.P. 2001. The effect of cooking on the location and concentration of oxalate in three cultivars of New Zealand-grown oca (Oxalis tuberosa Mol). J. Sci. Food Agric. 81: 1-7.

Aletor, V.A. 1995. Compositional studies on edible tropical species of mushrooms. Food Chem. 54: 265- 268. 
Arnott, H.J. and Whitney K. D.1984. Calcium oxalate crystal formation in a species of Hypoderma (Basidiomycetes). In Proceedings of the 42nd Annual Meeting of the Electron Microbiology Society of America, ed. GW Bailey, p. 320. San Francisco, CA: San Francisco Press.

Biswas, M. K. and Biswas, S. 2015. Recycling of lingo-cellulosic waste materials through oyster mushroom cultivation for sustainable food production. The Ecoscan. (34):655659

De Bary, A. 1887. Comparative morphology and biology of the fungi, mycetozoa and bacteria. Oxford: Clarendon Press

Shitole, A.V., Gade M, Bandgar. M.S., Wavare. S. H and Belkar Y. K. 2014. Utilisatioon of spent mushroom substrate as carrier for biocontrol agent and biofertilizer. The Bioscan 9(1): 271-275.

Fassett, D.W. 1973. Oxalates. In Toxicants Occurring Naturally in Foods, 2nd edn, pp. 346-362. Washington, DC: National Academy of Sciences.

Franceschi, V.R. and Loewus, F.A. 1995. Oxalate biosynthesis and function in plants and fungi. In HJ Arnott (1995): Calcium oxalate in fungi. In Calcium Oxalate in Biological Systems, ed. SR Khan, pp. 113-130. New York: CRC Press

Fujita, T., Komemushi, S. and Yamagata, K.
1991. Contents of amino acids, organic acids and 59-nucleotides in Tricholoma giganteum. J. Sci. Food Agric. 55: 159- 162

Gontzea, I. and Sutzescu, P. 1968. Natural antinutritive substances in foodstuffs and forages. S Karger, pp. 84-108. Basel.

Hein, I. 1930. Studies on the mycelium of Psalliota campestris. Am. J. Bot. 17: 197.

Holloway, W.D., Argall, M.E., Jealous, W.T., Lee, J.A. and Bradbury, J.H. 1989. Organic acids and calcium oxalate in tropical root crops. J. Agric. Food Chem. 37: 337-341.

Murashige, T. and Skoog, F.A 1962. Medium. revised, rapid. for, growth, with. bioassays, tissue. Tobacco, cultures, Physiol. Plant. 15: 473-479.

Noonan, S.C. and Savage, G.P.1999. Oxalate content of foods and its effect on human metabolism. Asia Pacific $J$. Clin. Nutr. 8: 64-74.

Savage, G.P., Vanhanen, L., Mason, S.M. and Ross, A.B. 2000. Effect of cooking on the soluble and insoluble oxalate content of some New Zealand foods. J. Food Comp. Anal. 13: 201- 206.

Sarma,T.C., Sarma, I. and Patiri, B. N. 2010. Wild edible mushrooms used by some ethnic tribes of western Assam. The Bioscan. 3: 613-625.

\section{How to cite this article:}

Rishu Sharma and Binoy Gorai. 2018. Estimation of Soluble, Insoluble and Total Oxalate Contents in Common Edible Mushrooms of West Bengal, India. Int.J.Curr.Microbiol.App.Sci. 7(07): 264-268. doi: https://doi.org/10.20546/ijcmas.2018.707.031 